\title{
EKSISTENSI “MABLEUEN” DI ERA PERSALINAN MODERN: STUDI ANTROPOLOGI KESEHATAN DI KECAMATAN SAWANG KABUPATEN ACEH UTARA
}

\author{
Lia Elfida \\ Program Studi Antropologi, Fakultas Ilmu Sosial dan Ilmu Politik \\ Universitas Malikussaleh \\ Korespondesi: liaelfida077@gmail.com
}

\begin{abstract}
Abstrak: Artikel ini bertujuan untuk mengetahui eksistensi mableun terhadap persalinan modern di Kecamatan Sawang Kabupaten Aceh Utara. Mableuen sampai saat ini masih diakui oleh masyarakat karena metode persalinan yang membuat si ibu bayi tidak perlu melakukan operasi. Penulisan skripsi ini disusun dengan menggunakan pendekatan penelitian data kualitatif, yaitu penelitian dengan mengumpulkan data lapangan kemudian dibahas dan dianalisis dengan mengacu pada landasan teoritis. Proses penggalian dalam mengumpulkan data ini penulis melakukan observasi, wawancara serta pengumpulan dokumen yang berkaitan dengan eksistensi Mableuen di era persalinan modern. Eksistensi Mableuen masih sangat diharapkan oleh masyarakat dengan alasan bahwa Mableuen mampu melestarikan adat istiadat, budaya dan tradisi masyarakat mengenai proses persalinan. Adaptasi Mableuen di era persalinan modern berjalan dengan cukup baik, antara Mableuen dan Bidan desa melakukan kerjasama yang mampu memberikan kekompakan antara satu dengan lain, apalagi saat ini Mableuen sudah difasilitasi dengan pelatihan kusus masalah persalinan.
\end{abstract}

Kata Kunci: Mableuen, Bidan Desa, Masyarakat, Persalinan 


\section{A. Pendahuluan}

Masalah kesehatan bagi penduduk di Kota maupun di pedesaan masih saja merupakan masalah diterapkan dan dikembangkan belum berjalan dengan baik, baik itu program kesehatan baru maupun program kesehatan hasil modifikasi program lama. Banyak pelayanan kesehatan yang belum memadai. Indikator yang penting adalah kematian ibu dan bayi yang masih tinggi (Alia, 2010: 13). Seringkali, program kesehatan menemui kegagalan karena di coba untuk dijalankan hanya semata-mata dengan berpedoman kepada pertimbangan teknis medis yang kaku. Salah satu program yang belum mencapai sasaran sebagaimana yang di harapkan adalah pertolongan persalinan (Prawirohardjo, 2008: 90).

Hampir di seluruh Kabupaten Aceh Utara khususnya Kecamatan Sawang, persalinan masih saja dibantu oleh dukun bayi (mableuen). Tenaga dukun bayi (mableuen) sejak dahulu kala sampai sekarang merupakan pemegang peranan penting dalam pelayanan kebidanan. Menurut Kartika (2004: 67) dalam lingkungan dukun bayi (mableuen) merupakan tenaga terpercaya dalam segala soal yang terkait dengan reproduksi wanita. Ia selalu membantu pada masa awal kehamilan sampai mengurus ibu dan bayinya selesai persalinan hingga masa nifas. Menurut Ketua Mitra Peduli Kependudukan (2006: 112) dukun bayi (mableuen) biasanya seorang wanita yang sudah berumur lebih kurang 40 tahun ke atas.

Paradigma positivis dalam ilmu pengetahuan modern membuat batasan nyata antara dunia fisik dan metafisika. Definisi kebenaran berkaitan dengan bagaimana akal atau rasio bisa menerima suatu pernyataan dan bisa dibuktikan secara empiris. Paradigma positivis dalam dunia modern telah melahirkan ahli-ahli kesehatan spesialistik dan mereduksi praktik-praktik kesehatan mistis yang lebih bersifat holistik. Peran dan fungsi dukunpenyembuh pada masa tradisional digantikan oleh dokter dan lembaga-lembaga kesehatan modern (Anggorodi, 2009: 24).

\section{B. Metode Penelitian}

Dalam penelitian ini penulis menggunkan metode kualitatif, yaitu penelitian dengan mengumpulkan data lapangan yang kemudian di bahas dan dianalisis dengan mengacu pada landasan teoritis. Pendekatan yang penulis lakukan adalah 
Perspektif Antropologi Kesehatan. Metode Medeleine Leininger (1985:45) telah mengembangkan strategi penelitian tentang Antropologi Kesehatan yang terfokus pada pelayanannya. Strategi penelitian itu dinamakan penelitian etno pelayanan kesehatan, yang muncul dari teori Leininger untuk pelayanan kesehatan antar budaya. Penulis mengambil perspektif ini karena objek yang diteliti adalah tentang pelayanan kesehatan dan eksistensi pelakunya yang dikenal dengan sebutan dukun bayi (mableuen).

Informan dalam penelitian ini adalah Mableuen, masyarakat dan keuchik gampong. Dalam hal ini teknik pengumpulan data yang penulis lakukan adalah observasi, wawancara studi dokumen atau studi literatur. Keseluruhan informan berjumlah 60 orang yang diambil berdasarkan pengambilan data dengan metode purposive sampling. Teknik analisis data secara kualitatif dengan menggunakan metode analisis interaktif. Analisis data dilakukan sepanjang proses penelitian dengan mengikuti tahapan analisis sebagai berikut:

1. Triangulasi (pemeriksaan ulang) untuk mendapatkan informasi yang benarbenar akurat dalam memperoleh data lapangan.

2. Menghubungkan data yang diperoleh di lapangan dengan studi literatur untuk menyempurnakan hasil temuan yang bermakna.

3. Menarik kesimpulan berdasarkan hasil penelitian yang diperoleh melalui observasi, wawancara serta studi literatur

Melakukan penafsiran ulang terhadap kesimpulan guna menghindari kekeliruan terhadap data yang diperoleh.

\section{Pembahasan}

\section{Eksistensi Mableuen di Masyarakat Balang Cut}

Eksistensi adalah keberadaan, kehadiran yang mengandung unsur bertahan. Eksistensi adalah suatu proses yang dinamis, suatu, menjadi atau mengada. Ini sesuai dengan asal kata eksistensi itu sendiri, yakni exsistere, yang artinya keluar dari, melampaui atau mengatasi. Jadi eksistensi tidak bersifat kaku dan terhenti, melainkan lentur atau kenyal dan mengalami perkembangan atau sebaliknya kemunduran, tergantung pada kemampuan dalam mengaktualisasikan potensipotensinya. 
Keberadaan mableuen sampai saat ini masih juga diperlukan meskipun sebagai mableuen tradisional tetapi ia juga mengikuti berbagai pelatihan yang diadakan oleh pihak Puskesmas setempat. Dan dalam praktiknya mableuen telah bekerjasama dengan bidan dan pihak Puskesmas setempat.

Mableuen sampai saat ini sudah menjadi kepercayaan masyarakat, sehingga Mableuen tidak hanya dipercayai dalam proses persalinan. Namun, Mableuen juga dipercayai dalam proses perawatan kehamilan. Dimana setiap kehamilan dan treatment awal sampai akhir ditangani dengan baik oleh Mableuen. Beberapa peran yang dilakukan Mableuen pada periode kehamilan dalam perspektif masyarakat meliputi: 1) Mableuen dilibatkan dalam upacara empat bulanan atau tujuh bulanan, 2) membetulkan posisi janin, 3) memijit ibu hamil, dan 4) memotivasi cek kehamilan di Pusat Pelayanan Kesehatan. Pada periode kehamilan masih banyak yang menggunakan jasa Mableuen dalam perawatannya disamping menggunakan perawatan medis modern. Peran pertama Mableuen pada periode kehamilan adalah dilibatkan dalam upacara empat bulanan dan tujuh bulanan dan membetulkan posisi janin,

Setelah Mableuen dilibatkan pada upacara empat bulan dan tujuh bulanan, selanjutnya tidak terbatas waktu seorang ibu hamil dapat meminta tolong jasanya untuk memijat. Misalnya kondisi ibu hamil mengalami pegal di kaki, tangan atau punggung, jika perlu maka dapat meminta Mableuen untuk memijitnya.Faktanya tidak semua klien pada awalnya menyadari kehamilannya atau sengaja menunda pengecekan kehamilan. Pada masa ini Mableuen akan menyarankan klien untuk periksa ke bidan.

\section{Mableuen dan Persalinan}

Dalam melakukan persalinan Mableuen mempunyai tahapan-tahapan khusus yang harus dilakukan agar proses persalinan berjalan dengan baik dan lancar. Tahapan-tahapan tersebut yaitu adanya peralatan yang digunakan, baik welat maupun sebagainya. cara pertolongan persalinan dan ramuan khusuus yang diberikan untuk Ibu dan bayi. Ramuan tersebut biasanya terbuat dari bahan alami tanpa adanya unsur kimia.

a) Peralatan Yang digunakan Mableuen Saat Persalinan 
Peralatan yang digunakan Mableuen pada saat proses persalinan berbeda dengan apa yang digunakan oleh bidan. Awalnya Alat yang digunakan dalam pemotongan placenta adalah welat yaitu sebuah pisau yang terbuat dari bambu, kemudian berganti menjadi gunting, dan terakhir adalah gunting khusus. Namun pada saat ini Mableuen harus menggunakan gunting dikarenakan welat jarang bisa ditemukan.

Pemotongan Placenta menjadi pusat perlakuan khusus bagi bayi. Pemotongan yang salah terhadap placenta akan berakibat fatal bagi jabang bayi sehingga dalam hal ini Mableuen menggunakan cara, teknik, dan ramuan-ramuan tradisional untuk melakukan pemotongan placenta tersebut. Cara pemotongan placenta dilakukan dengan memegang erat ujung yang menjadi batas ari-ari menurut perhitungan mableuen, kemudian mulai melakukan pemotongan dengan pisau yang terbuat dari bambu, kemudian bekas luka dibalut dengan garam, kunyit, dan njet.

Jika ibu bayi dalam keadaan sudah terdesak, Mableuen biasanya menggunakan ilmu Sulushoh (ilmu khusus turun temurun untuk melakukan proses persalinan tanpa operasi), ilmu tersebut digunakan apabila memang sudah terdesak yang mengakibatkan banyak pendarahan dan jika bayi betu-betul tidak mau keluar. b) Cara Pertolongan Persalinan

Cara pertolongan persalinan yang dilakukan oleh Mableuen pada umumnya masih dengan cara serta alat yang sederhana. Dan melalui tahapan-tahapan pertolongan persalinan. Cara pertolongan persalinan oleh Mableuen bersifat tradisional baik teknik maupun alat yang digunakannya. Langkah-langkah pertolongan persalinan oleh Mableuen sama halnya dengan proses persalinan pada umumnya, sehingga tidak ada teknik tertentu atau syarat-syarat khusus untuk pasien ketika akan bersalin. Mableuen hanya akan menunggu calon ibu sampai waktunya tiba untuk melahirkan. Dalam hal ini yang menjadi pusat perhatian dalam serangkaian persalinan adalah pemotongan tali pusar atau placenta pada bayi. Menurut kepercayaan setempat, placenta ini adalah kakang kawah atau saudara kembar dari bayi yang harus diperlakukan dengan baik dan memiliki kekuatan magic sehingga didalam pemotongan dan penguburannya harus dilakukan oleh Mableuen tersebut. 
Tahapan-tahapan persalinan yang dimaksud yaitu:

1) Tahap pertama, persiapan tempat bersalin

Dukun bayi menyiapakan tempat bersalin dengan menggelar alas Serta memposisikan calon ibu dengan duduk senden.

2) Tahap kedua, pemijatan

Dukun bayi melakukan pemijatan terhadap calon ibu pada bagian kaki, paha, serta perut sambil membacakan mantera untuk memberikan perlindungan kepada ibu dan bayi. Sementara itu sang suami berada tepat dibelakang istri untuk menopang sambil mengunyah sebuah ramuan dari dukun bayi yang kemudian disemburkan ke ubun-ubun sang istri.

3) Tahap ketiga, pemotongan tali pusat setelah turunnya plasenta.

Proses ini dilakukan dengan menggunakan pisau bambu yang telah diberi mantera khusus. Setelah itu dilakukan proses pengolesan kunyit pada tunggal tali pusat untuk mempercepat proses pengeringan luka.

4) Tahap keempat, penguburan ari-ari.

Proses penguburan ari-ari ini dilakukan dengan membacakan mantera yang dimaksudkan agar bayi terhindar dari bahaya, ari-ari dikuburkan di sekitar halaman rumah.

5) Tahap terakhir yaitu pencucian bekas alas melahirkan istri (kopohan).

Pada tahap ini khusus dikerjakan oleh suami. Proses ini disertai dengan ritual bakar kemenyan, merang, bunga, dan wangi-wangian serta pembacaan mantera yang diajarkan oleh dukun bayi.

Masyarakat percaya bahwa pertolongan persalinan yang diberikan Mableuen cukup baik untuk calon ibu dan calon bayi tersebut. Dikarenakan persalinan yang dilakukan oleh Mableuen sesuai berdasarkan tradisi mereka. Walaupun saat ini banyak masyarakat yang sudah membuang tradisi tersebut.

c) Ramuan Yang digunakan Mableuen Pada Ibu Bayi

Pasca melahirkan, seorang ibu mendapatkan perhatian dan perawatan khusus dari Mableuen yang membantu persalinananya. Diantaranya adalah perawatan dengan memberikan ramuan tradisional. 

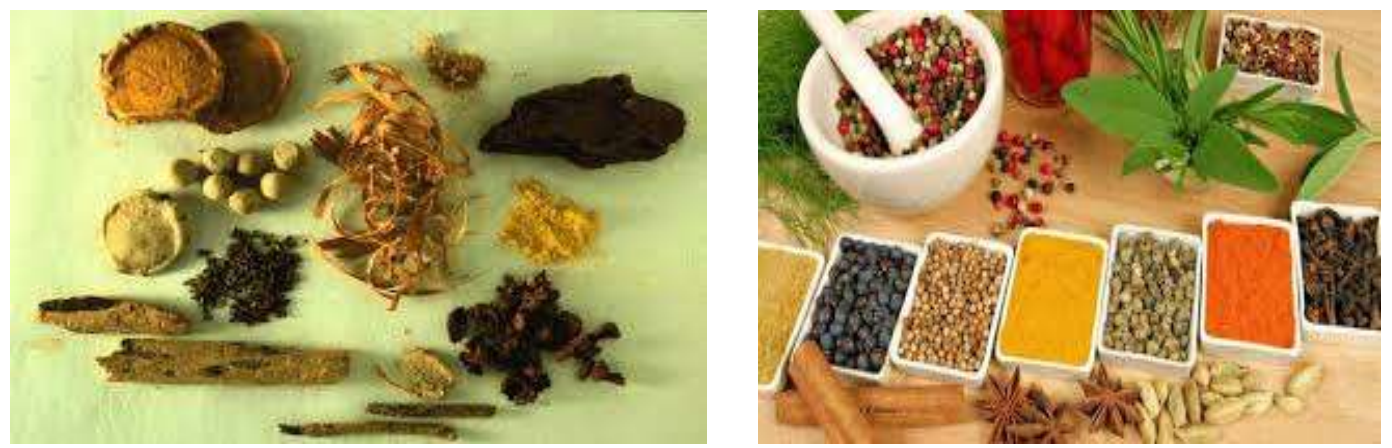

Foto Ramuan Yang digunakan oleh Mableuen

Selain berupa ramuan, perawatan pasca melahirkan berupa mandi khusus yaitu sang ibu bayi mandi dengan mengguyur badannya mulai dari kepala dan seluruh tubuh, dengan mata tetap terbuka dan tiap kali bersamaan dengan guyuran air, ibu bayi harus membuka mulutnya untuk menghembuskan udara. mandi dengan cara seperti ini ditujukan untuk menjaga ibu bayi dari gangguan makhluk halus.

Pasca melahirkan Mableuen menggunakan Param (sejenis obat-obatan dari kunyit) pada tubuh ibu bayi. Kegunaan param tersebut yaitu untuk memulihkan tenaga ibu bayi pasca melahirkan. Param biasanya terbuat dari kunyit, dan akatakar ilalang. Tidak hanya param ibu bayi juga akan diberikan jamu asam yang terbuat dari daun sirih, asam jawa dan kunyit. Kegunaan jamu tersebut untuk mengembalikan bentuk tubuh ibu bayi menjadi ideal kembali.

Pada zaman sebelumnya keberadaan mableuen sangat diperlukan, dikarenakan mereka memiliki keahlian dalam hal pertolongan persalinan secara tradisional, sebagai konsultan bayi dan ibu bayi, serta memiliki kemampuan secara magis dalam praktiknya sebagai seorang mableuen. Keahliannya tidak hanya dikenal oleh warga sekitar tetapi juga sampai pada warga di daerah lain. Mableuen Kecamatan Sawang tidak berjumlah sebanyak dulu, untuk saat ini Mableuen di tempat tersebut hanya berjumlah 3-5 orang saja.

\section{Peran Mableun dalam Perawatan Pasca Persalinan}

Setelah kelahiran, mableuen memiliki tanggung jawab mendampingi ibu dan bayi selama bulan pertama kelahirannya, yaitu dengan memberikan perawatan lanjutan berupa pijit bagi keduanya dalam konteks pemulihan pasca persalinan oleh ibu dan kesehatan bagi bayi. Pada sembilan hari kelahiran bayi, mableuen 
melakukan pijit pada bayi. Hal ini dimaksudkan agar tubuh sibayi tidak rentan dari penyakit dan memantapkan organ-organ tubuh pada bayi selain itu mableuen juga membantu memandikan bayi serta memberikan ramuan-ramuan tradisional agar bayi tidak mudah rewel. Karena pada usia ini, bayi masih rentan terhadap kekuatankekuatan gaib yang ada disekelilngnya sehingga diperlukan pagar atau penangkal oleh mableuen.

Perawatan yang diberikan mableuen berlangsung sampai selapanan, yaitu usia bayi menginjak pada 1 bulan kelahirannya tetapi, mableuen tidak lagi memandikannya dan hanya datang seminggu dua kali untuk memijit bagi bayi.

Secara umum dukun bayi akan terus mendampingi bayi sampai 45 hari kelahiranya. Selama rentang waktu tersebut perkembangan bayi akan tetap dipantau oleh dukun bayi yang menangani kelahirannya dengan cara mengunjungi tempat tinggal bayi. Pemberian nama pada bayi dilakukan pada hari kelima kelahirannya dan dihadiri oleh dukun bayi yang menangani kelahirannya. Acara tersebut dikenal sebagai acara sepasaran. Pada acara tersebut dukun bayi memotong sehelai rambut bayi dengan diberikan doa-doa tertentu sebagai syarat jalannya ritual. Kemudian pada usia 45 hari kelahirannya diadakan selapanan yaitu pencukuran seluruh rambut bayi, hal ini juga dilakukan oleh dukun bayi yang membantu kelahirannya, pencukuran seluruh rambut bayi tersebut memiliki maksud dan tujuan agar kelak rambut bayi tumbuh dengan bagus dan secara magis bayi tidak mudah rewel dan lemah terhadap penyakit.

Setiap kehidupan manusia akan mengalami perubahan. Perubahan itu dapat mengenai nilai-nilai sosial, norma-norma sosial, pola prilaku, perekonomian, lapisan-lapisan sosial dalam masyarakat, interaksi sosial dan yang lainya. Perubahan sosial terjadi pada semua masyarakat dalam setiap proses dan waktu, dampak perubahan tersebut dapat berakibat positif dan negatif. Terjadinya perubahan merupakan gejala yang wajar dalam kehidupan manusia. Hal ini terjadi karena setiap manusia mempunyai kepentingan yang tidak terbatas.

Perubahan sosial adalah proses sosial yang dialami masyarakat serta semua unsur-unsur budaya dan sistem-sistem sosial, dimana semua tingkat kehidupan masyarakat secara suka rela atau di pengaruhi oleh unsur-unsur eksternal meninggalkan pola-pola kehidupan, budaya dan sistem sosial yang baru. Perubahan 
sosial terjadi pada dasarnya karena ada anggota masyarakat pada waktu tertentu merasa tidak puas lagi terhadap keadaan kehidupanya yang lama dan menganggap sudah tidak puas lagi atau tidak memadai untuk memenuhi kehidupan yang baru termasuk dalam proses persalinan.

Secara umum masyarakat memandang Mableuen sebagai seorang yang memiliki kemampuan lebih atau supranatural dalam menekuni profesinya. Hanya Mableuen yang dapat melakukan pertolongan persalinan dan cepat tanggap mengenai kemungkinan terjadinya kesulitan kelahiran dengan kemampuan yang dimiliki dukun bayi.

Sebagai seorang penolong persalinan tradisional mableuen juga mendapatkan berbagai pelatihan-pelatihan medis dan program-program kesehatan yang diadakan oleh pihak puskesmas setempat terkait dengan penanganan bayi dan cara pertolongan persalinan secara sehat dan bersih. Dengan ikut sertanya mableuen dalam program- program yang dicanangkan oleh pihak puskesmas tersebut telah terbina hubungan yang baik antara keduanya sehingga dalam menjalankan tugasnya sebagai dukun tradisional mendapatkan pengawasan dari pihak tenaga medis, khusunya puskesmas.

Adaptasi mableuen dengan persalinan modern semakin ditingkatkan dengan menjalin hubungan yang sangat baik antara bidan dengan mableuen. Pasalnya, salah satu bidan yang bertugas di Puskesmas pada daerah tersebut adalah anak dari mableuen tersebut. Oleh sebab itu, ketika mableuen mengalami kesulitan dalam menangani persalinan pasien maka mableuen akan membuat rujukan atas alih fungsi penanganan mableuen kepada bidan. Atau kerjasama lain ditunjukkan ketika proses persalinan dilakukan oleh mableuen, bidan seringkali terlibat dalam proses tersebut.

Mableuen yang menekuni profesi sebagai penolong persalinan secara tradisional, mendapatkan apresiasi baik dari warga masyarakat khususnya bidan. Mereka berasumsi, keberadaan Mableuen dan praktiknya berarti telah melestarikan budaya yang secara turun-temurun dijalankan pada peristiwa diseputar kelahiran seorang bayi. Hal ini sejalan dengan teori solidaritas mekanik Emile Durkheim yang mengatakan bahwa, "Dalam masyarakat yang menganut solidaritas mekanis, yang diutamakan ialah persamaan peilaku dan sikap. Perbedaan tidak dibenarkan". 


\section{Eksistensi Mableuen di Era Persalinan Modern}

Profesi Mableuen masih banyak di gunakan masyarakat terutama di pedesaan. Meski sudah ada jasa bidan, penduduk desa lebih cenderung melahirkan ke Mableuen. Mableuen adalah seorang perempuan yang diakui oleh masyarakat dalam mendampingi ibu hamil, pertolongan persalinan serta perawatan bayi baru lahir secara spiritual. Umumnya masih banyak masyarakat yang mempercayakan dukun untuk membantu proses persalinannya. Di dalam Masyarakat tradisional masalah kesehatan terkait dengan budaya setempat karena sebenarnya banyak masyarakat yang menggangap bahwa kelahiran adalah proses alami bukan sebuah proses medis.

Peran Mableuen mencerminkan budaya. Hingga kini sebagian masyarakat terutama para ibu masih memilih menggunakan jasa Mableuen untuk membantu proses persalinan. Walaupun sekarang sudah jaman modern masih memerlukan tenaga Mableuen sebagai pendamping dalam mengawasi kehamilan disaat tenaga bidan tidak bisa melakukan pengawasan secara penuh dan disuatu daerah yang masih kurangnya tenaga bidan. Layanan yang diberikan oleh tenaga kesehatan nonmedis atau Mableuen:

a. Mableuen biasanya adalah orang yang di kenal masyarakat setempat.

b. Biaya pertolongan persalinanMableuenjauh lebih murah daripada tenaga kesehatan, Mableuen mematok harga murah, kadang bisa disertai atau diganti dengan sesuatu barang misalnya beras, kelapa, dan bahan dapur lainnya.

c. Pelayanan Mableuen di lakukan sampai ibu selesai masa nifas.

d. Masyarakat masih terbiasa dengan cara-cara tradisional

e. Mableuen menemani anggota keluarga agar bisa beristirahat dan memulihkan diri, sebaliknya bidan seringkali tidak bersedia saat dibutuhkan atau bahkan tidak mau datang saat dipanggil.

Masyarakat di pedesaan, masih lebih percaya kepada Mableuen dari pada kepada bidan. Masih banyak masyarakat yang memilih persalinan ditolong oleh tenaga kesehatan non medis daripada tenaga kesehatan disebabkan oleh beberapa faktor antara lain tingkat pendidikan yang rendah, status dalam masyarakat 
Aceh Anthropological Journal, Vol. 4, No. 2 , hlm: 213-224, Oktober 2020

terhadap penyuluhan dan pertugas kesehatan rendah dan tingkat kepercayaan masyarakat terhadap penyuluhan dan pertugas kesehatan masih rendah.

\section{Kesimpulan}

Berdasarkan hasil penelitian, maka dapat diambil kesimpulan sebagai berikut:

1. Eksistensi mableuen masih diharapkan oleh warga dengan alasan faktor ekonomi, adat-istadat, tradisi, sugesti masyarakat serta kemantapan masyarakat serta faktor kepercayaan. Adapun selama menjalankan profesinya, mableuen telah memiliki ijin praktek dari pemerintahan daerah setempat dan telah mengikuti berbagai pelatihan-pelatihan medis dibidangnya sehingga pertolongan persalinan dapat dilakukan secara bersih dan sehat dan masyarakat tidak perlu meragukan keahlian sebagai tenaga tradisional.

2. Adaptasi mableuen baik lingkungan maupun budaya sangat baik. Apalagi sampai saat ini mableuen diberikan wewenang untuk menangani proses persalinan dengan mengikuti pelatihan yang diadakan oleh pihak puskesmas setiap bulannnya. 


\section{Daftar Pustaka}

Alia, Mirna Nur. 2010. Belian Sasak Di Tengah Pengobatan Modern. Yogyakarta: Yayasan Penerbitan Fakultas Sosiologi Universitas Gadjah Mada.

Anggorodi, Rina. 2009. Dukun Bayi Dalam Persalinan Oleh Masyarakat Indonesia. Makara Kesehatan Vol 13, No.1 Juni pp.1-15

Bandiyah, Siti. 2009. Buku Kesehatan Keperawatan dan Gangguan Kehamilan. Yogyakarta: Nuha Medika.

Parawihardjo. 2008. Ilmu Kandungan. Jakarta: Yayasan Bina Pustaka Sarwono Prawirohardjo.

Sarwono. 2007. Pelayanan Kesehatan Maternal dan Neonatal. Jakarta: YBP-SP

Salmah. 2006. Asuhan Kebidanan Aternatal. Jakarta: Buku Kedokteran EGC.

Sylviati. Savitri. 2008. Gizi Ibu Hamil. Jakarta: Balai Penerbit FKUL

http://id.wikipedia.org/wiki/Perspektif disambiguasi. Di akses pada tgl 8 Mei 2015, pukul 16.46.

http://boulluwellwinda.blogspot.com/2013/05/definisi-paraji.html, di akses pada tgl 8 Mei 2015 pukul 09.32 WIB.

http://kti-kedokteran.blogspot.com/2011/10/definisi-dukunbayi_597.html.diakses pada tgl 8 Mei 2015 pukul 16.45WIB. 